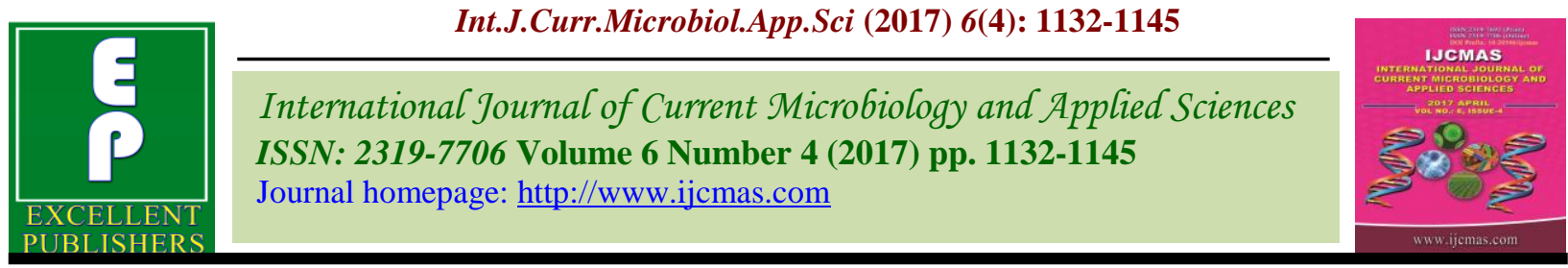

Review Article

https://doi.org/10.20546/ijcmas.2017.604.140

\title{
An Overview of Spatial Variability of Soil Microbiological Properties using Geostatistics
}

\author{
Juvaria Jeelani*, Nayar Afaq Kirmani, Javed Ahmad Sofi, Shakeel Ahmad Mir, \\ Javed Ahmad Wani, Rehana Rasool and Syed Sadat
}
Division of Soil Science, Sher e Kashmir University of Agricultural Science and Technology, Kashmir, Shalimar, Srinagar, 190025, India
*Corresponding author

\begin{tabular}{|c|c|}
\hline & A B S T R A C T \\
\hline & \multirow{6}{*}{$\begin{array}{l}\text { Soil forms an integral part of the ecosystem and at present the quality of a soil is defined } \\
\text { not only in terms of its productive capacity, but also by taking the ecosystem into } \\
\text { consideration. Consequently, when soil productivity has to be maximized, environmental } \\
\text { effects must be given proper consideration. Thus the changes in soil quality caused by } \\
\text { different types of land use must first be quantified for attaining sustainability in use and } \\
\text { management. In order to understand the soil function on a firm scientific basis one cannot } \\
\text { neglect the biological and biochemical processes taking place in the soil. Microbiological } \\
\text { parameters form an important component of the soil ecosystem perturbations. Information } \\
\text { on soil microorganisms and their activity used to determine microbiological characteristics } \\
\text { are very important for soil quality and productivity. Studies of enzyme activities also } \\
\text { provide information on the biochemical processes occurring in soil. Moreover the soil } \\
\text { biological parameters are considered to be the potential and sensitive indicators of soil } \\
\text { ecological conditions and management. Therefore mapping of these properties helps to } \\
\text { determine the level of spatial variability of these properties in soil. Geostatistical methods } \\
\text { can be satisfactorily used to evaluate the soil microbiological parameters statistically. } \\
\text { Geostatistics consists of modeling the spatial variation to create the semivariogram and } \\
\text { kriging to produce maps. Semivariograms describe the semivariance between sampling } \\
\text { locations at a different lag distance. Kriging is a linear interpolation procedure that } \\
\text { provides estimates at unsampled sites. }\end{array}$} \\
\hline Keywords & \\
\hline $\begin{array}{l}\text { Geosta } \\
\text { Enzyn } \\
\text { Dehyd } \\
\text { Semiv }\end{array}$ & \\
\hline Article Info & \\
\hline $\begin{array}{l}\text { Accepted: } \\
12 \text { March } \\
\text { Available } \\
10 \text { April } 20\end{array}$ & \\
\hline & \\
\hline
\end{tabular}

\section{Introduction}

The living population inhabiting soil includes macrofauna, mesofauna, microfauna and microflora that control the ecosystem functioning. This is done through decomposition and nutrient cycling which serve as the important indicators of land-use change and ecosystem health (Doran and Zeiss 2000; Waldrop et al. 2000; Yao et al. 2000). They play significant role for enhancing soil fertility as well as plant growth and are involved in many biochemical reaction including nutrient transformation and mineralization activities in soils. However, the study of soil microorganisms is difficult and our current understanding limited. The first step towards increase in the knowledge of these microbiological parameters and to bring a change in its scenario is to know the degree of spatial variability of these soil properties. This is considered to be the most critical step in the decision making process for a more rational management of soil, be it 
for corrective and accurate fertilizer application or any other activity towards sustainability. According to McGraw (1994), soil spatial variability occurs at different degrees and is due to the intrinsic variability or extrinsic variability. Intrinsic variability results from the variations in the parent material, climate, relief, organisms and time, i.e., the processes of soil formation whereas extrinsic variability is mainly due to human activities such as crop production practices or the effects of management practices in the area (Rao and Wagenet, 1985). Both the method of cultivation and management practices are found to have greater influence on the activity of soil microflora (McGill et al., 1980). Soil biological parameters are effective indicators of environmental stress, management practices (Dick and Tabatabai, 1992) and management induced changes in soil quality (Dick, 1992; Kennedy and Papendick, 1995). Soil biological properties and processes vary spatially at different scales. In many instances spatial variation in these properties is not random but tends to follow a pattern in which variability decreases as distance diminishes between points in space (Youden and Mehlich, 1937; Warrick and Nielsen, 1980). Spatial dependence has been observed for a wide range of soil physical, chemical, and biological properties and processes (Yost et al., 1982; Wollum and Cassel, 1984; Cahn et al., 1994; Cambardella et al., 1994; von Steiger et al., 1996; Amador et al., 1997; Lyons et al., 1998; Go“rres et al., 1998; Raun et al., 1998). Soil is fundamental and irreplaceable entity; it governs plant productivity of terrestrial ecosystems and it maintains biogeochemical cycles because of microorganisms which possess the ability to degrade all organic compounds including persistent xenobiotics and naturally occurring polyphenolic compounds. This has aroused a particular interest in the relation between soil biodiversity and function in the soil and is a part of a general concern to conserve biodiversity and its role in maintaining a functional biosphere. Moreover, by characterizing diversity one will be able to understand and manipulate the working of ecosystems and the ability of an ecosystem to withstand serious disturbances. Also changes in the microbial community structure are likely to be reflected in the functional integrity of the soil (Insam, 2001), because the microbial communities influence the potential of soils for enzyme mediated substrate catalysis (Kandeler et al., 1996). It has been found that $80-90 \%$ of the processes in soil are reactions mediated by microbes and is considered to give the relationship between microbial diversity and soil functionality (Coleman and Crossley, 1996; Nannipieri and Badalucco, 2003). Indeed, bacteria and fungi are highly versatile; they can carry out almost all known biological reactions. But the problem lies in measuring microbial diversity and microbial functions in the soil. At present the link between microbial diversity and soil functions is not fully explained. So, the research is needed for a better evaluation and manipulation of microbial diversity and soil functionality.

\section{Geostatistical tools for measuring spatial variability}

A number of statistical tools have been reportedly used in the study of spatial variability of soil properties (Reichardt and Timm 2008). Of these, geostatistics is worth mentioning, which allows the detection of the variability structure and spatial distribution of soil properties in a given area and quantitatively describe spatial variation by expressing a measure of association, or autocorrelation, between two samples which is a function of the distance between them. Incorporation of functions that relate distance and variance among points are semivariograms. Variogram involves plotting the relationship between the semivariance 
$(\boldsymbol{\gamma}(\boldsymbol{h}))$ and the lag distance $(\boldsymbol{h})$ (Iacozza and Barber 1999).

$$
\gamma(h)=\frac{1}{2 N(h)} \sum_{i=1}^{N(h)}(Z(x i)-Z(x i+h))
$$

where: $\gamma(\mathrm{h})$ is experimental semivariance, $\mathrm{N}(\mathrm{h})$ is the number of pairs of measured values $\mathrm{Z}\left(\mathrm{x}_{\mathrm{i}}\right), \mathrm{Z}\left(\mathrm{x}_{\mathrm{i}}+\mathrm{h}\right)$ separated by a vector (h). In geostatistics, $\mathrm{Z}\left(\mathrm{x}_{\mathrm{i}}\right)$ is described as regionalized variable (McGrath et al. 2004).

To study the spatial structure of soil properties semivariograms and autocorrelograms have been typically used. This has greatly reduced the need for expensive and intensive sampling for different soil properties, as in the case of precision agriculture (McBratney and Pringle, 1999). Geostatistical analysis are commonly used in soil and mineral science, but have not been used much for exploring the microbial ecology. A number of functions are available to be fitted in a particular situation like the linear, Gaussian, exponential and spherical models. A linear variogram indicates a linear spatial gradient representing a situation where the samples are spatially autocorrelated at all distances measured. Gaussian, exponential and spherical models, on the other hand are bounded, they level off, either at a given range value (spherical model) or asymptotically (exponential and Gaussian models). These functions differ mostly in the shape of the left-hand portion of the curves while near the origin, the spherical and exponential models do not differ by much. Semivariogram has three important characteristic parameters which are distinguished as the nugget, sill and range. When the function of semivariogram increases not from zero but from a certain other value, it is called the nugget effect $\left(\mathrm{C}_{0}\right)$. The value at which the semivariogram function does not increase any further and this value is found to be approximately equal to the sample variance $\left(\mathrm{s}^{2}\right)$ is sill, whereas the distance from zero to the point at which 95\% of the constant value has been reached by the semivariogram, is range. Spatial dependence of soil properties can be obtained by taking the ratio of nugget variance to sill and is expressed in percentages. If this ratio is less than $25 \%$, then the variable has strong spatial dependence; if the ratio is between 25 and $75 \%$, the variable has moderate dependence; otherwise, the variable has weak dependence (Chien et al., 1997). Spatial analysis of soil microbiological properties has added advantage of assessing soil quality and health, as well as for developing appropriate sampling strategies. Besides these the geostatistical analyses have been used to estimate the spatial variability soil biochemical properties (Bonmati et al., 1991; Sutherland et al., 1991), pesticide distribution in soil (Rao and Wagenet, 1985; Wood et al., 1987), soil microbiological processes (Ailken et al., 1991; Rochette et al., 1991), and ecological parameters (Robertson, 1987; Rossi et al., 1992). Geostatistics can be applied to detect, estimate and map the spatial patterns of micribiological variables in a field. It is based on modelling and interpretation of the semivariogram which relates dissimilarity between paired data values to the distance between each sample pair (Goovaerts, 1997; Isaaks and Srivastava, 1989; Journel and Huijbergts, 1978; Rossi et al., 1992). The next and the important step in geostatistics is the interpolation which is the process of estimating values at unknown points using known values for the sample points. This method can be divided into deterministic (create surfaces from measured points) and geostatistical (utilize the statistical properties of the measured points) techniques (Pereira $e t$ al., 2013a,b; Bogunovic et al., 2014; Xie et al., 2011). Kriging is a geostatistical technique of exact interpolation based on a statistical model (Krige, 1951). The model 
used allows interpolation of data to unsampled areas based on values at neighbouring points (Sunila et al., 2004). It is an optimal method because the interpolation weights are chosen to provide for the value at a given point, the Best Linear Unbiased Estimate (BLUE) (Jesus 2003). This method is also linear weighted averaging method but the weights given in this method depends not only on distance but also on the direction and orientation of the neighbouring data.

\section{Microbiological indices}

Soil enzyme activities provide information about microbial status and physico-chemical condition of soils and are thus regarded as the "sensors" of soil organic matter (SOM) decomposition (Aon - Colaneri, 2001; Baum et al., 2003). All soils contain a group of enzymes that determine its metabolic processes (McLaren, 1975) which, in turn, depend on its physical, chemical, microbiological and biochemical properties (Makoi and Ndakidemi, 2008). Enzymatic processes participate in the processing of making unavailable forms of nutrients readily available, to be assimilated by plants and is closely related to the soil quality (Sinsabaugh et al., 1994). These enzyme activities are very sensitive to both natural and anthropogenic disturbances, and readily respond to the induced changes in soil ecosystems (Dick, 1997). Soil enzymes assays are used for monitoring of microbial activity related to specific nutrient transformations (Sinsabaugh, 1994). A number of factors affect these enzyme activities like environmental factors (temperature, moisture etc.), agricultural practices such as soil tillage, usage of pesticides and fertilizers, soil amendment with organic residues (Dick, 1992; Bergstrom et al., 1998) and, pollution with heavy metals (Baath, 1989; Giller, 1998; Kizılkaya et al., 2004; Kızılkaya and Bayrakl1, 2005). The spatial variability of soil enzyme activities has been examined by using classical statistical approaches (Bonmati et al., 1991). However, geostatistics is becoming increasingly popular among soil scientists for assessing spatial variability of soil microbiological properties (Trangmar et al., 1985; Goovaerts, 1998; Askin et al., 2004; Askin and Kizilkaya, 2005, 2006; Kizilkaya and Askin, 2004, 2005). Enzymes that are likely involved in carrying out soil microbiological processes are dehydrogense, urease, phosphatase, aryl sulphatase etc.

Soil dehydrogenase (DHA) is one of the important soil enzymes participating in and assuring the correct sequence of all the biochemical routes in soil biogeochemical cycles (Ladd 1985). Large amount of information about biological characteristic of the soil is obtained by the determination of DHA in soil (Wolinska and Stepniewska, 2012). Dehydrogenase enzyme is often used as a measure of soil microbial activity and gives account of any disruption caused by pesticides, trace elements or management practices to the soil (Chendrayan et al., 1979; Trevors et al., 1982; McCarthy et al., 1994). Soil DHA is considered to exist in soils as integral parts of intact cells (Taylor et al., 2002). Dehydrogenase enzyme performs the process of oxidation of soil organic matter by transferring protons and electrons from substrates to acceptors (Makoi and Ndakidemi, 2008). These steps are part of respiration pathways of soil micro-organisms and are closely related to the type of soil and soil air-water conditions (Kandeler et al., 1996). Several environmental factors, including soil moisture, oxygen availability, oxidation reduction potential, $\mathrm{pH}$, organic matter content, depth of the soil profile, temperature, season of the year, heavy metal contamination and soil fertilization or pesticide use can significantly affect DHA in the soil environment (Dkhar and Mishra, 1983; Baruah and Mishra, 1984; Sinsabaugh 
et al., 2008; Xiang et al., 2008; Wolinska and Stepniewska, 2012; Kumar et al., 2013).

Soil respiration $(R \mathrm{~s})$ is the emission of carbon dioxide from soils. It is the second largest flux of carbon between terrestrial ecosystems and the atmosphere, constituting $20-38 \%$ of the annual atmospheric input of $\mathrm{CO}_{2}-\mathrm{C}$ (Raich and Schlesinger, 1992). Soil respiration is mainly from heterotrophic $(R \mathrm{~h})$ and autotrophic $(R \mathrm{a})$ sources: $R \mathrm{~s}=R \mathrm{~h}+R \mathrm{a}$. The heterotrophic part comprises of the microbial decomposition of soil organic matter, whereas the autotrophic part is the result of the metabolism of plant roots (Tang and Baldocchi, 2005). Soil respiration $(R \mathrm{~s})$, the sum of respiration by soil organisms $(R \mathrm{~h})$ and roots $(R a)$, is known to be highly variable in both, space and time. There is limited information available about the behaviour of $R \mathrm{~h}$ and $R \mathrm{a}$ in time and particularly in space. The spatial pattern of respiration in soil is a mixture of the patterns of the heterotrophic and autotrophic component. Autotrophic component can increase the spatial variability of heterotrophic component, if the root system adds heterogeneity, depending on the land use type. For example crops planted in rows, e.g. maize, reveal higher rates of respiration in soil close to the rows due to the increased root respiration (Rochette et al., 1991). A quite similar case is the soil respiration in forests, where the respiration is higher close to the stems, due to increasing root density (Tang and Baldocchi, 2005) and higher amounts of litter (Fang et al., 1998).

Spatial variability of soil organic carbon (SOC) is an important indicator of soil quality, as well as carbon pools in the terrestrial ecosystem and it's important in ecological modeling, environmental prediction, precision agriculture, and natural resources management (Zhang et al., 2012, Liu et al., 2014). Revealing the characteristics of SOC's spatial pattern will provide the basis for evaluating soil fertility, and assist in the development of sound environmental management policies for agriculture. Scientific management of SOC nutrient is important for its sustainable development in agricultural system. So, there is a need of adequate information about spatio-temporal behavior of SOC over a region.

\section{Spatial analysis of microbial properties using the tool of geostatistics}

It has been found that the variability of microbiological parameters is higher than that of chemical parameters (Bonmati et al., 1991; Rover and Kaiser, 1999). Morris (1999) also reported the weak spatial dependence of the physico-chemical soil properties whereas microbial biomass and their activities showed strong spatial dependence. Mummey et al. (2002) suggested that the central role in establishing heterogeneity and regulating ecological processes was the plant cover. Plants contribute to soil heterogeneity by their effects on soil moisture, aeration, $\mathrm{pH}$ etc., and by the litter distribution and all these factors determine enzyme synthesis by microbes and enzyme survival outside the microbial cells. As microbial biomass is affected by several factors it is not as reproducible as chemical measurements and shows high spatial variability (Powlson, 1994). In a study, spherical anisotropic model was the best semivariogram model for DHA. The ratio of nugget to total variation of DHA was $22.1 \%$, indicating strong spatial dependence of this microbiological property. Because DHA has a strong spatial dependence, a large number of sampling points is required to estimate a representative value of DHA. The range for this enzyme was $48.2 \mathrm{~km}$. This information can be used to gain a better understanding of the spatial distribution of dehydrogenase activity (Kizikaya and Askin, 2007). IPU mineralization rate, organic $\mathrm{N}$ and genetic structure of the microbial communities were 
studied by Sebai et al., (2007). The spatial structure and geostatistical maps for these biological parameters were formulated. Comparison of these maps revealed comparable in-field spatial variation in all the three parameters. Although these results showed an enhanced biodegradation of IPU by soil microflora generally, considerable spatial variation in the degradation rate of IPU was observed across the field. It was noted that those patches which were poor in their ability to mineralize IPU showed low soil $\mathrm{pH}$ and microbial $\mathrm{C}$ biomass also. This was in confirmation with the results of earlier studies that have recorded similar positive relationship between soil $\mathrm{pH}$ and total microbial biomass (Walker et al., 2000). Spatial variability for pesticide biodegradation has been recorded widely, however recently variation in pesticide adsorption and efficacy for pesticides like carbofuran, atrazine, alachlor, and 2,4dichlorophenoxyacetic acid (2,4-D) have been noted (Parkin and Shelton, 1992; Beck et al., 1996; Liu et al., 2002; Vieuble-Gonod et al., 2003). The results also establish that study of variation in pesticide biodegradation provides idea about the behavior of herbicide in soils, ultimately recharging the aquifers, possesses spatial variation too. This is the principal reason for the spatial heterogeneity of soil $\mathrm{pH}$ and microbiological $\mathrm{C}$ biomass and proposes the need to determine the spatial variability of soil $\mathrm{pH}$ and soil microbial $\mathrm{C}$ biomass when modeling kinetics of pesticide in order to provide a more reliable prediction of pesticide transfer to water resources.

Another microbial process such as carbon mineralization showed greater small scale variability than physical processes because of the requirement of spatial coincidence of the appropriate size and type of microbial community as well as quality and quantity of substrate at the micrometer scale (Amador et $a l ., 2000)$. These factors are known to vary considerably in space at even $\mathrm{cm}$ scale. Similarly, Parkin (1987) found that the rate of denitrification in soil varies significantly even at the $\mathrm{cm}$ scale and is strongly dependent on the spatial distribution of microbially available carbon.

On studying spatial variability of microbial biomass carbon in lowland cultivated irrigated rice Parfitt et al., (2009) found that the degree of spatial dependence was strong for MBC and variables with strong spatial dependence $(\leq 25 \%)$ are the most influenced by soil composition characteristics, such as original material, climate, organisms and time Cambardella et al. (1994).

Table 1 shows the parameters for the models fitted to the experimental semivariograms of the attributes studied. Loureiro et al., (2010) studied the biological attributes in the area of alley cropping and found that the attributes with spatial dependence were C, FLF, SMB$\mathrm{N}$ and respiration, and the best fit model to these attributes was the spherical model. However In the area of pasture, $\mathrm{C}$ and microbial $\mathrm{C} / \mathrm{N}$ ratio showed spatial dependence with the fitting of Gaussian model respectively. The range value for SMB-N in the area of alley cropping was 5.5 $\mathrm{m}$ as estimated by the semivariogram. This explains high sensitivity of this variable to the applied management, where the spacing between rows of $6 \mathrm{~m}$ for Gliricidia, might have influenced the pattern of spatial variability of SMB-N. Since Gliricidia is a $\mathrm{N}_{2}$ fixing tree legume, it generates a gradient of organic matter and SMB-N between the cropping rows. In contrast to it the bush garden area did not show any spatial dependence for the attributes of microbial biomass and labile constituents of SOM. The main reason for random pattern of variability of SMB and labile constituents in the area of bush garden might be due to the random input of organic matter from forest litter to the soil 
(different species, size, and amount) where the trees were settled originally in the area in a random distribution.

Nayanaka et al. 2010 studied the geostatistical analysis of organic $\mathrm{C}$ in the paddy growing Alfisol (Figure 1). It was found that the organic carbon was spatially related to a distance of $300 \mathrm{~m}$. Relative Nugget Effect (RNE) which indicates the proportion of spatially unstructured variation in relation to the total variation is $9.28 \%$. This value falls in a class of strongly structured spatial dependence $(<25 \%)$. According to the variogram, for spatial characterization of soil organic carbon in this area, samples can be taken within a sampling interval of $300 \mathrm{~m}$.

The study of spatial variability of heterotrophic and autotrophic respiration in winter wheat showed that there is a random spatial structure for $\mathrm{Rh}$ (heterotrophic respiration) (Prolingheur et al., 2010). The reason for the predominantly random structure of $R \mathrm{~h}$ might be the small scale spatial variability of the microbial communities and carbon pools (Nunan et al., 2002). High spatial variations in the autotrophic component was detected which attributed to the heterogeneity in local root development, which then mainly caused the variability of total soil respiration in space. During the final period of plant growth, when the root system is almost fully developed, autotrophic spatial variations are at maximum. It has been found that total soil respiration and the autotrophic component showed moderate to strong spatial dependence in contrast to a predominantly random distribution of $R \mathrm{~h}$ in space. The lack of spatial autocorrelation in the heterotrophic component pattern is mostly responsible for the stochastic variations in the total soil respiration pattern. The variogram analysis revealing differences in the spatial structures of $R \mathrm{~h}$ and $R \mathrm{a}$ are given in table 2 .
Stark et al., 2004 studied spatial variability of selected biological properties (Microbial biomass carbon and nitrogen and Arginine deaminase activity) to determine relationships between soil microbial diversity and nutrient loss by leaching. Geostatistical analysis and fitting of an exponential model showed that a spatial structure exists in the biotic soil properties and that the samples are independent beyond separation distances of $25-30 \mathrm{~cm}$.

Another study also reported that the microbial properties exhibited greater spatial dependence. It was found that the variation $>50 \%$ was associated with microbial biomass and net nitrification potentials and exhibited a spatial component; $30-40 \%$ of the variation was associated with soil respiration potentials and net $\mathrm{N}$-mineralization potentials also appeared to be somewhat spatially dependent with a range of 20-30 m except for soil respiration potentials, for which dependence was ranged up to $60 \mathrm{~m}$. In all these cases model sample variance was found close to actual sample variance. For biomass, $45 \%$ of model sample variance was spatially dependent to a range of $93 \mathrm{~m}$ (Robertson et al., 1997) (Tables 3 and 4).

The kriging variance is calculated by the spatial distribution in the enzyme activity estimation maps. All monitored enzyme data can be well fitted by Exponential, Gaussian and Spherical models, mostly by Exponential model, and with determination coefficient for all above 0.69, which indicates that semivariate analysis could successfully be used for assessing the spatial distribution characteristics of enzyme activities (Gao et al., 2010).

Nugget value generally found to be affected by experimental error or sample variance in small scale, and sill generally caused by total variability of the inner system. 
Table.1 Estimated values of semivariograms for some microbiological attributes (Loureiro et al., 2010)

\begin{tabular}{|l|l|l|l|l|l|l|}
\hline Attributes** & Model* & Co & C1 & Co/(Co+C1 $*^{*} 100$ & Range & r 2 \\
\hline C & Espherical & 0 & 0.69 & 0 & 13 & 0.79 \\
\hline FLF & Espherical & 0.000004 & 0.00005 & 0.79 & 7.9 & 0.91 \\
\hline SMB-N & Espherical & 0 & 35.5 & 0 & 5.5 & 0.47 \\
\hline Respiration & Espherical & 0.016 & 0.009 & 64 & 13.4 & 0.49 \\
\hline Pasture & \multicolumn{5}{|l|}{} \\
\hline C & Gaussian & 0.15 & 0.24 & 38.5 & 10.3 & 0.87 \\
\hline C/Nmic & Gaussian & 0.53 & 1.16 & 31.4 & 13.1 & 0.80 \\
\hline
\end{tabular}

Selected models by cross-validation (jacknife); $\mathrm{C}_{0}$ : nugget effect; $\mathrm{C}_{1}$ : sill; ${ }^{* *} \mathrm{C}$ : organic carbon; FLF: free light fraction; SMB-N: nitrogen of soil microbial biomass; C/Nmic: microbial carbon/nitrogen ratio.

Table.2 Variogram parameters of soil respiration for selected sampling dates (Prolingheur et al., 2010)

\begin{tabular}{|l|l|l|l|l|l|l|l|l|l|l|l|l|l|l|l|l|}
\hline & \multicolumn{9}{l|}{$\begin{array}{l}\text { Heterotrophic } \\
(R \mathrm{~h})\end{array}$} \\
\hline Date & $c_{0}$ & $c_{1}$ & $n_{\mathrm{c}}$ & $a_{1}$ & $r^{2}$ & $c_{0}$ & $c_{1}$ & $n_{\mathrm{c}}$ & $a_{1}$ & $r^{2}$ & $c_{0}$ & $c_{1}$ & $n_{\mathrm{c}}$ & $a_{1}$ & $r^{2}$ \\
\hline 16 Apr & 0.009 & 0.012 & 0.43 & 7.6 & 0.09 & 0.010 & 0.000 & 1.00 & 0.0 & 0.00 & 0.025 & 0.018 & 0.59 & 14.4 & 0.55 \\
\hline 22 Apr & 0.021 & 0.003 & 0.87 & 17.9 & 0.03 & 0.019 & 0.004 & 0.82 & 35.1 & 0.45 & 0.082 & 0.011 & 0.88 & 23.6 & 0.57 \\
\hline 30 Apr & 0.004 & 0.013 & 0.26 & 13.1 & 0.74 & 0.016 & 0.000 & 0.99 & 22.7 & 0.20 & 0.033 & 0.012 & 0.73 & 19.1 & 0.21 \\
\hline 5 May & 0.002 & 0.030 & 0.06 & 7.4 & 0.63 & 0.016 & 0.000 & 1.00 & 0.0 & 0.00 & 0.000 & 0.225 & 0.00 & 13.7 & 0.77 \\
\hline 13 May & 0.045 & 0.034 & 0.57 & 26.0 & 0.46 & 0.016 & 0.012 & 0.57 & 10.0 & 0.21 & 0.021 & 0.106 & 0.16 & 23.6 & 0.73 \\
\hline 20 May & 0.009 & 0.027 & 0.26 & 19.0 & 0.93 & 0.007 & 0.014 & 0.34 & 8.7 & 0.81 & 0.006 & 0.052 & 0.10 & 24.1 & 0.96 \\
\hline 27 May & 0.020 & 0.000 & 1.00 & 0.0 & 0.00 & 0.010 & 0.003 & 0.76 & 23.3 & 0.64 & 0.005 & 0.134 & 0.04 & 11.7 & 0.83 \\
\hline 28 May & 0.006 & 0.011 & 0.35 & 10.5 & 0.72 & 0.019 & 0.000 & 1.00 & 0.0 & 0.00 & 0.000 & 0.094 & 0.00 & 7.5 & 0.71 \\
\hline 3 Jun & 0.015 & 0.002 & 0.86 & 23.2 & 0.12 & 0.002 & 0.009 & 0.21 & 10.9 & 0.90 & 0.008 & 0.011 & 0.42 & 19.5 & 0.88 \\
\hline 17 Jun & 0.003 & 0.006 & 0.36 & 23.1 & 0.95 & 0.016 & 0.000 & 1.00 & 0.0 & 0.00 & 0.082 & 0.054 & 0.60 & 8.7 & 0.51 \\
\hline 24 Jun & 0.022 & 0.000 & 1.00 & 0.0 & 0.00 & 0.004 & 0.020 & 0.18 & 6.1 & 0.10 & 0.000 & 0.078 & 0.00 & 11.2 & 0.30 \\
\hline 1 Jul & 0.005 & 0.003 & 0.63 & 14.6 & 0.14 & 0.015 & 0.000 & 1.00 & 0.0 & 0.00 & 0.003 & 0.109 & 0.03 & 4.7 & 0.00 \\
\hline 15 Jul & 0.005 & 0.015 & 0.23 & 35.1 & 0.78 & 0.026 & 0.000 & 1.00 & 0.0 & 0.00 & 0.007 & 0.004 & 0.62 & 28.1 & 0.56 \\
\hline 22 Jul & 0.019 & 0.000 & 1.00 & 0.0 & 0.00 & 0.000 & 0.015 & 0.03 & 13.4 & 0.84 & 0.004 & 0.006 & 0.44 & 11.8 & 0.84 \\
\hline
\end{tabular}

$c 0$ : nugget, $c 1$ : structural variance, $n \mathrm{c}$ : nugget coefficient $(c 0(c 0+c 1)-1), a 1$ : range of spatial autocorrelation, $r 2$ :

coefficient of determination of fit. Values

for $c 0$ and $c 1$ are given in $\log 10(\mu$ molm-2 s-1)2 and values given for $a 1$ are given in meters.

Table.3 Parameters of autocorrelation in Cmic, Nmic and ADA based on best-fit lines derived from exponential model (Stark et al., 2004)

\begin{tabular}{|l|l|l|l|l|l|l|l|}
\hline & & $(\mathrm{C} 0)$ & Sill $(\mathrm{C}=\mathrm{C} 0+\mathrm{C} 1)$ & Spatial dependence & $\mathrm{R} 2$ & $\mathrm{P}$ & range \\
\hline Cmic & ORG & 824 & 16292 & 0.95 & 0.99 & 0.001 & 43 \\
\hline & CON & 1110 & 3075 & 0.64 & 0.98 & 0.018 & 31 \\
\hline & average & 958 & 8788 & 0.89 & 0.98 & 0.003 & 13 \\
\hline Nmic & ORG & 21 & 333 & 0.94 & 0.99 & 0.002 & 31 \\
\hline & CON & 27 & 61 & 0.56 & 0.96 & 0.04 & 25 \\
\hline & average & 23 & 184 & 0.88 & 0.99 & $<0.001$ & 22 \\
\hline ADA & ORG & 0.023 & 0.126 & 0.82 & 0.81 & 0.082 & 179 \\
\hline & CON & 0.016 & 0.028 & 0.44 & 0.67 & 0.327 & 48 \\
\hline & average & 0.019 & 0.047 & 0.60 & 0.81 & 0.081 & 36 \\
\hline
\end{tabular}


Table.4 Variogram model parameters for biological properties of soil (Robertson et al., 1997)

\begin{tabular}{|c|c|c|c|c|}
\hline \multirow[b]{2}{*}{ Property } & \multicolumn{4}{|c|}{ Model parameters } \\
\hline & $C /(C 01 C)$ & Range (m) & $r 2$ & $s 2$ \\
\hline \multicolumn{5}{|l|}{ Microbial properties } \\
\hline Culturable bacteria & $-\dagger$ & $-\dagger$ & $-\dagger$ & 0.511 \% \\
\hline Biomass C & 0.542 & 21.0 & 0.497 & 0.146 * \\
\hline Respiration & 0.341 & 61.2 & 0.420 & 0.135 t \\
\hline Net nitrification & $\mathbf{0 . 5 5 9}$ & 25.5 & 0.579 & $0.013 \backslash \backslash$ \\
\hline Net $\mathrm{N}$ mineralization & 0.407 & 28.4 & 0.483 & 0.013 \\
\hline \multicolumn{5}{|l|}{ Plant properties } \\
\hline Biomass & 0.440 & 93.0 & 0.855 & 6937. \\
\hline $\mathbf{N}$ content & 0.560 & 51.3 & 0.700 & 0.210 \\
\hline
\end{tabular}

Spatial structure not apparent. + Skewness and kurtosis calculated following lognormal transformation $[\ln (z)]$ of original

values. \Skewness and kurtosis calculated following lognormal transformation $[\ln (z \quad 1 \quad 1)]$ of original values.

Fig.1 Experimental semivariograms of $\mathrm{MBC}$ and organic carbon in different soils (Parfitt et al., 2009; Nayanaka et al., 2010)

MBC- spherical semivariogram

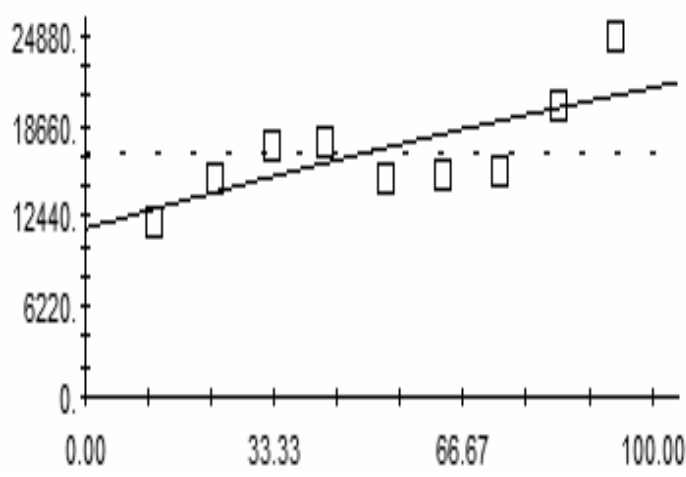

It is seen that the sill value for enzyme distribution was almost three times higher than the nugget value for enzyme distribution, which indicates that the spatial semivariance for the different enzyme distribution mostly comes from the inner system, not caused by sample variance in small scale. The ratio of the nugget value to the sill value describes the spatial variable characteristic. The higher values indicate that the spatial variability is mostly affected by random factors and can also be described by the spatial correlation.

In conclusion, knowledge of the spatial

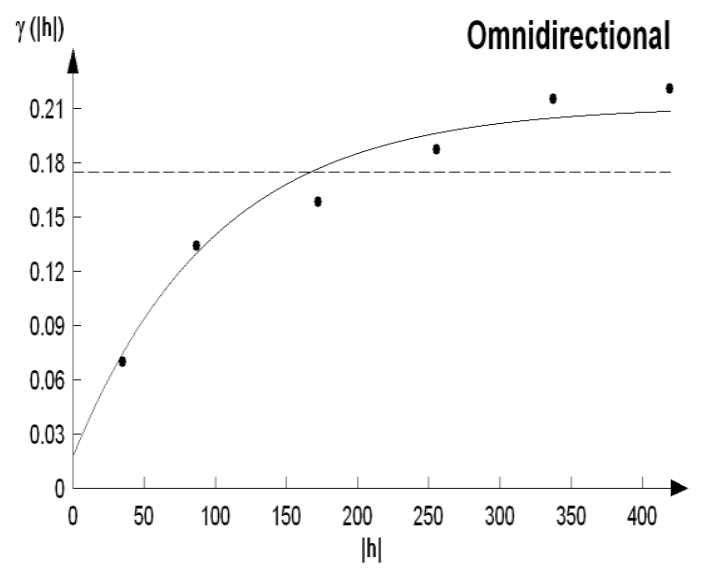

variability of microbial soil properties is very advantageous and can be helpful in understanding the fertility of the soil, especially as more site-specific agriculture is being practiced as a step to attain sustainability. Spatial variability and geostatistical mapping is equally important for understanding ecosystem processes, microbial diversity and microbial-soil organic matter interactions and provides the structured variance. With the advancement in information technologies especially in modern software tools such as spatial 
geostatistics and geographical information system (GIS) integration of large and complex databases has been made possible, models, tools and techniques have been developed, and are proposed to improve the process of soil quality and sustainability.

\section{References}

Ailken, R.M., Jawson, M.D., Grahammer, K., Polymenopoulos, A.D., 1991. Positional, spatially correlated and random components of variability in carbon dioxide flux. Journal of Environmental Quality 20, 301-308.

Amador, J.A., Glucksman, A.M., Lyons, J.B., Go“rres, J.H., 1997. Spatial distribution of soil phosphatase activity within a riparian forest. Soil Sci. 162, 808-825.

Amador, J. A. Wang, Y. Savin, M. C. Gorres, J.H. 2000 Fine-scale spatial variability of physical and biological soil properties in Kingston, Rhode Island Geoderma 98:8394

Aon, M. A. and Colaner, A. C. (2001): Temporal and spatial evolution of enzymatic activities and physico-chemical properties in an agricultural soil. Applied Soil Ecology 18: 255-270.

Aşkın T., Kızılkaya R., Ozdemir, N. (2004). Th e spatial variability of soil dehydrogenase activity: a study in pasture soils. International Soil Congress (ISC) on Natural Resource Management for Sustainable Development, Soil Science Society of Turkey, June 7-10, Erzurum, Turkey, N.1-N.11, pp 7-14.

Aşkın T. and Kizilkaya R. (2005). The spatial variability of urease activity of surface agricultural soils within an urban area. J. Central Eur.Agric. 6(2): 161-166.

Aşkın T. and Kizilkaya R. (2006). Assessing spatial variability of soil enzyme activities in pasture topsoils using geostatistics. Eur. J. Soil Biol. 42: 230-237.

Baath E. (1989). Eff ects of heavy metals in soil on microbial processes and populations (a review). Water, Air, Soil Pollut. 47: 335379.

Baruah, M. and Mishra, R. R. (1984):
Dehydrogenase and urease activities in rice field soils. Soil Biology and Biochemistry 16: 423-424.

Baum, C., Leinweber, P. and Schlichting, A. (2003): Effects of chemical conditions in re-wetted peats temporal variation in microbial biomass and acid phosphatase activity within the growing season. Applied Soil Ecology 22: 167-174.

Beck, A.J., Harris, G.L., Howse, K.R., Johnston, A.E., Jones, K.C., 1996. Spatial and temporal variation of isoproturon residues and associated sorption/ desorption parameters at the field scale. Chemosphere 33, 1283-1295.

Bergstrom D.W., Monreal C.M., King D.J. (1998). Sensitivity of soil enzyme activity to conservation practices. Soil Sci. Soc.Am. J. 62:1286-1295

Bogunovic I, Mesic M, Zgorelec Z, Jurisic A, Bilandzija D. 2014: Spatial variation of soil nutrients on sandy-loam soil. Soil Till. Res. 144: 174-183.

Bonmati M., Ceccanti B., Nannipieri P. (1991). Spatial variability of phosphatase, urease, protease, organic carbon, and total nitrogen in soil. Soil Biol. Biochem. 23:391-396

Cahn, M.D., Hummel, J.W., Brouer, B.H., 1994. Spatial analysis of soil fertility for sitespecific crop management. Soil Sci. Soc. Am. J. 58, 1240-1248.

Cambardella, C.A., Moorman, T.B., Novak, J.M., Parkin, T.B., Karlen, D.L., Turco, R.F. and

Konopka, A.E. 1994. Field-scale variability of soil properties in Central Iowa soils. Soil Sci. Soc. Am. J., 58:1501-1511.

Chendrayan, K., Ahlya, T. K. and Sethunathan, N. (1979): Dehydrogenase and invertase activities of flooded soils. Soil Biology and Biochemistry 12: 217-273.

Chien Y.J., Lee D.Y., Guo H.Y., Houng K.H. (1997). Geostatistical analysis of soil properties of mid-west Taiwan soils. Soil Sci.162:291-298

Coleman, D.C. and Crossley, D.A. 1996. Fundamentals of Soil Ecology. Academic Press, London.

Dkhar, M. S. and Mishra, R. R. (1983): Dehydrogenase and urease activities of maize (Zea mays L.) filed crops. Plant and Soil 70: 327-333. 
Dick R.P. (1992). A review: long-term effects of agricultural systems on soil biochemical and microbial parameters. Agric. Ecosyst. Environ. 40:25-36

Dick W.A., Tabatabai M.A. (1992) Potential uses of soil enzymes. In: Metting FB (ed) Soil microbial ecology: applications in agricultural and environmental management. Marcel Dekker, New York, pp 95-127

Dick R.P. (1997). Soil enzyme activities as integrative indicators of soil health. In: Pankhurst C.E., Doube B.M., Gupta V.V.S.R. (Eds.) Biological indicators of soil health.,CAB International, New York,USA, pp 121-156

Doran JW, Zeiss MR. 2000. Soil health and sustainability: managing the biotic component of soil quality. Appl Soil Ecol 15(1):3-11.

Fang, C., Moncrieff, J. B., Gholz, H. L., and Clark, K. L. 1998. Soil CO2 efflux and its spatial variation in a Florida slash pine plantation, Plant Soil, 205, 135-146.

Gao, Y., Mao, L., Miao, C., Zhou, P., Cao, J., Zhi, Y., Shi, W., 2010. Spatial characteristics of soil enzyme activities and microbial community structure under different land uses in Chongming Island, China: geostatistical modelling and PCR-RAPD method. The Science of the Total Environment 408, 3251-3260.

Giller K.E., Witter E., McGrath S.P. (1998). Toxicity of heavy metals to microorganisms and microbial processes in agricultural soils: a review, Soil Biol. Biochem. 30: 1389-1414

Goovaerts P. 1998. Geostatistics in soil science: state-of-the-art and perspectives. Geoderma (in press).

Go"rres, J.H., DiChiaro, M.J., Lyons, J.B., Amador, J.A., 1998. Spatial and temporal patterns of soil biological activity in a forest and an old field. Soil Biol. Biochem. 30, 219-230.

Iacozza J, Barber D. 1999. An Examination of the Distribution of Snow on Sea-Ice. Atmosphere-Ocean, 37pp. $21-51$.

Isaaks EH, Srivastava RM. 1989. An Introduction to Applied Geostatistics. Oxford University Press, New York, p 500.
Insam, H. 1997. Substrate utilization tests in microbial ecology. Journal of Microbiological Methods, 30, 1-2.

Jesus R. 2003. Kriging: An Accompanied Example in IDRISI. GIS Centrum University for Oresund Summer University, Sweden.

Journel, A.G., Huijbergts, C.J., 1978. Mining Geostatistics. Academic Press, London.

Kandeler, E. (1996): Nitrate. In: Schinner, F., Öhlinger, R., Kandeler, E. and Margesin, R. (ed).

Methods in soil biology. Springer. Berlin, Heidelberg, New York. pp. 408-410.

Kennedy A.C., Papendick R.I. (1995).Microbial characteristics of soil quality. J. Soil Water Conserv. 50: 243-248.

Kizilkaya R., Askin T. (2004). Alkaline phosphatase activity of surface agricultural soils within an urban area. International Soil Congress (ISC) on Natural Resource Management for Sustainable Development, Soil Science Society of Turkey, June 7-10, Erzurum, Turkey, N.1-N.11, pp 15-21.

Kızılkaya R., Aşkın T. (2005). The spatial variability of arylsulphatase activity in agricultural ecosystems. Second Congress of Azerbaijan Soil Science Society on Soil Recourses; Their Use and Protection, November 10-14, Baku, Azerbaijan, pp 409-418

Kizilkaya R., Bayrakh B. (2005). Eff ects of Nenriched sewage sludge on soil enzyme activities. Appl. Soil Ecol. 30: 192-202.

Kizilkaya, R., Aşkin, T., 2007. The spatial variability of soil dehydrogenase activity: a survey in urban soils. Agriculturale Conspectus Scientificus 72, 89-94.

Kumar, S., Chaudhuri, S. and Maiti, S. K. (2013): Soil Dehydrogenase Enzyme Activity in Natural and Mine Soil - A Review. MiddleEast Journal of Scientific Research 13: 898-906.

Krige DG. 1951. A statistical approach to some basic mine valuation problems on the Witwatersrand. J Chemical, Metallurgical and Mining Soc. South Africa. 52: 119139.

Ladd, J. N. (1985): Soil enzymes. In: Soil Organic Matter and Biological Activity. Nijhoff, Dordecht. 
Liu, H.S., Li, L.H., Han, X.G., Huang, J.H., Sun, J.X., Wang, H.Y., 2006. Respiratory substrate availability plays a crucial role in the response of soil respiration to environmental factors. Applied Soil Ecology 32:284-292.

Liu, L., Wang, H., Dai, W. and Li, X. 2014. Spatial variability of soil organic carbon in forestlands of northeast China. Journel of Forestry Research 25: 867-876.

Loureiro, D. C. Ceddia H P. Deaquino, M B, Maria. 2010. Spatial variability of microbial biomass and organic matter Labile pools in a haplic planosol soil. Bragantia, Campinas, 69:85-95.

Lyons, J.B., Go"rres, J.H., Amador, J.A., 1998. Spatial and temporal variability of phosphorus retention in a riparian forest soil. J. Environ. Qual. 27, 895-903.

Makoi, J. H. J. R. and Ndakidemi, P. A. (2008): Selected soil enzymes: Examples of their potential roles in the ecosystem. African Journal of Biotechnology 3: 181-191.

McBBratney AB and Pringle MJ. 1999. Estimating average and proportional variograms of soil properties and their potential use in Precision agriculture. Precision Agric. 1: 125-152.

McCarthy, G. W., Siddaramappa, R., Reight, R. J., Coddling, E. E. and Gao, G. (1994): Evaluation of coal combustion by products as soil liming materials: their influence on soil $\mathrm{pH}$ and enzyme activities. Biology and Fertility of Soils 17: 167-172.

Mc.gill, W.B., Cannon, K.R., Robertson, J.A. and Cook, F.D., 1980, Dynamics of soil microbial biomass and water stable organic carbon in Breton.L after fifty years of cropping rotation. Canadian Journal of Soil Science. 66: 1-19.

Mc Grath D, Zhang C, Carton TO. 2004. Geostatistical analysis and hazard assessment on a soil lead in silver mines area Ireland. Environ. pollution. 127: 239248

McGraw, T. 1994. Soil test level variability in Southern Minnesota.Better Crops Plant Foods, 78:24-25.

MCLaren, A. D. (1975): Soil as a system of humus and clay immobilised enzymes. Chemica Scripta 8: 97-99.
Morris, S.J., 1999. Spatial distribution of fungal and bacterial biomass in southern Ohio hardwood forest soils: fine scale variability and microscale patterns. Soil Biology and Biochemistry 31, 1375-1386.

Mummey, D.L., Stahl, P.D. and Buyer, J.S. (2002) Soil microbiological properties 20 years after surface mine reclamation: spatial analysis of reclaimed and undisturbed sites. Soil Biol. Biochem. 34, 1717-1725.

Nannipieri, P. and Badalucco, L. 2003. Biological processes. In: Processes in the Soil-Plant System: Modelling Concepts and Applications (eds D.K. Bembi and R. Nieder). The Haworth Press, Binghamton, $\mathrm{NY}$, in press.

Nayanaka, V.G.D. Vitharana, W.A.U. and Mapa R.B Geostatistical Analysis of Soil Properties to Support Spatial Sampling in a Paddy Growing Alfisol Tropical Agricultural Research 22(1): 34 - 44 (2010)

Nunan, N., Wu, K., Young, I.M., Crawford, J.W., Ritz, K., 2002. In situ spatial patterns of soil bacterial populations, mapped at multiple scales, in arable soil. Microbial Ecology 44, 296-305.

Parkin T. B. (1987) Soil microsites as a source of denitrification variability. Soil Science Society of America Journal 51, 1194-1199.

Parkin, T.B., Shelton, D.R., 1992. Spatial and temporal variability of carbofuran degradation in soil. Journal of Environmental Quality 21, 672-678.

Parfitt, J.M.B. Timm, L. C., Pauletto, E. A, de Sousa, R. O, Castilhos, D. D. de Ávila C L. Reckziegel, N L. 2009Spatial variability of the chemical, physical and Biological properties in lowland cultivated with irrigated rice, R. Bras. Ci. Solo, 33:819830 ,

Pereira $\mathrm{P}$, Cerdà A, Úbeda X, Mataix-Solera $\mathrm{J}$, Martin D, Jordán A, Burguet M. 2013b. Spatial models for monitoring the spatiotemporal evolution of ashes after fire-a case study of a burnt grassland in Lithuania. Solid Earth. 4: 153-165.

Powlson, D. S.1994.Measurement of soil microbial biomass provides an early indication of changes in total soil organic matter due to straw incorporation. Soil Biology and Biochemistry, v.19:159-164 
Prolingheuer, N. Scharnagl, B. Graf, A. Vereecken, H. Herbst M. 2010Spatial and seasonal variability of heterotrophic and autotrophic soil respiration in a winter wheat stand Biogeosciences Discuss., 7:9137-9173.

Raich, J. W. and Schlesinger, W. H. 1992. The global carbon-dioxide flux in soil respiration and its relationship to vegetation and climate, Tellus, 44B, 81-99, 9139.

Rao, P.S.C., Wagenet, R.J., 1985. Spatial variability of pesticides in field soils: methods for data analysis and consequences. Weed Science 33, $18 \mathrm{e} 24$.

Raun, W.R., Solie, J.B., Johnson, G.V., Stone, M.L., Whitney, R.W., Lees, H.L., Sembiring, $\mathrm{H}$.,

Philips, S.B., 1998. Microvariability in soil test, plant nutrient, and yield parameters in Bermudagrass. Soil Sci. Soc. Am. J. 62, 683-690.

Reichardt, K. and Timm, L.C. 2008. Solo, planta e atmosfera: Conceitos, processos e aplicações. São Paulo, Manole 478p.

Robertson, G.P., 1987. Geostatistics in ecology: interpolating with known variance. Ecology 68, 744-748.

Rochette, P., Desjardins, R. L., and Pattey, E. 1991. Spatial and temporal variability of soil respiration in agricultural fields, Can. J. Soil Sci., 71, 189-196.

Rossi RE, Mulla DJ, Journel AG, Franz EH. 1992. Geostatistical tools for modeling and interpreting ecological spatial dependence. Ecol. Monographs. 62:277-314.

Röver, M., Kaiser, E.-A., 1999. Spatial heterogeneity within the plough layer: low and moderate variability of soil properties. Soil Biology and Biochemistry 31, 175187.

Sebai, T.El., Lagacherie, B., Soulas, G., MartinLaurent, F., 2007. Spatial variability of isoproturon mineralizing activity within an agricultural field: geostatistical analysis of simple physicochemical and microbiological soil parameters. Environmental Pollution 145, 680-690.

Sinsabaugh R.L. (1994). Enzymis assay of microbial pattern and pocess. Biol Fertil Soils 17: 69-74.
Stark, C.H.E. Condrona, L.M.. Stewartb, A Dia, H.J. O'Callaghanc M. 2004. Small-scale spatial variability of selected soil biological properties. Soil, Plant and Ecological Sciences Division, PO Box 84, Lincoln University, Canterbury, NewZealand pp115

Sunila R, Laine E, Kremenova O. 2004. Fuzzy Modelling and kriging for imprecise soil polygon boundaries. In: Proceedings 12th International Conference on Geoinformatics - Geospatial Information Research: Bridging the Pacific and Atlantic, Gävle, Sweden, pp. $489-495$.

Sutherland RA, Kessel CV, Pennock D. 1991. Spatial variability of nitrogen-15 natural abundance. Soil Sci. Socie. Am. J. 55: 1339-1347.

Tang, J. W. and Baldocchi, D. D. 2005. Spatialtemporal variation in soil respiration in an oak-grasssavanna ecosystem in California and its partitioning into autotrophic and heterotrophic components, Biogeo chemistry, 73, 183-207.

Taylor, J. P., Wilson, B., Mills, M. S. and Burns, R. G. (2002): Comparison of microbial numbers and enzymatic activities in surface soils and subsoils using various techniques. Soil Biology and Biochemistry 34: 387401.

Trevors, J. T, Mayfield, C. I. and Inniss, W. E. (1982): Measurement of electron transport system (ETS) activity in soil. Microbial Ecology 8: 163-168.

Vieuble-Gonod, L., Chenu, C., Soulas, G., 2003. Spatial variability of 2,4dichlorophenoxyacetic acid (2,4-D) mineralisation potential at a millimeter scale in soil. Soil Biology and Biochemistry 35, 373-382.

Von Steiger, B., Nowack, K., Schulin, R., 1996. Spatial variation of urease activity measured in soil monitoring. J. Environ. Qual. 25, 1285-1290.

Waldrop MP, Balser TC, Firestone MK. 2000. Linking microbial community composition to function in a tropical soil. Soil Biol Biochem 32(13):1837-1846.

Walker, P. H., and R. V. Ruhe. 1968. Hill slope models in soil formation. II. Closed systems. Transactions of the Ninth 
International Congress of Soil Science (Adelaide, Australia) 4:561-569

Warrick, A.W., Nielsen, D.R., 1980. Spatial variability of soil physical properties in the field. In: Hillel, D. _Ed.., Applications of Soil Physics. Academic Press, New York, pp. 319-344.

Wolinska, A. and Stepniewska, Z. (2012): Dehydrogenase Activity in the Soil Environment, Dehydrogenases. Prof. Rosa Angela Canuto (ed). ISBN: 978-953-307019-3. InTech. DOI: 10.5772/48294.

Wollum, A.G.II., Cassel, D.K., 1984. Spatial variability of Rhizobium japonicum in two North Carolina soils. Soil Sci. Soc. Am. J. 48, 1082-1086.

Wood, L.S., Scott, H.D., Marx, D.B., Lavy, T.L., 1987. Variability in sorption coefficients of metolachlor on Captina silt loam. Journal of Environmental Quality 16, 251e256.

Xie Y, Chen TB, Lei M, Yang J, Guo QJ, Song B, Zhou XY. 2011. Spatial distribution of soil heavy metal pollution estimated by different interpolation methods: Accuracy and uncertainty analysis. Chemosphere. 82:
468-476.

Xiang, S.R., Doyle, A., Holden, P. A. and Schimel, J. P. (2008): Drying and rewetting effects on $\mathrm{C}$ and $\mathrm{N}$ mineralization and microbial activity in surface and subsurface California grassland soils. Soil Biology and Biochemistry 40: 2281-2289.

Yao H, He Z, Wilson MJ, Campbell CD (2000) Microbial biomass and community structure in a sequence of soils with increasing fertility and changing land use. Microb Ecol 40(3): 223-237.

Yost, R.S., Uehara, G., Fox, R.L., 1982. Geostatistical analysis of soil chemical properties of large land areas: I. Variograms. Soil Sci. Soc. Am. J. 46, $1028-1032$.

Youden, W.J., Mehlich, A., 1937. Selection of efficient methods for soil sampling. Trans. Boyce Thompson Inst. Plant Res. 9, 59-70.

Zhang, S., Huang, Y., Shen, C., Ye, H., Du, Y., 2012. Spatial prediction of soil organic matter using terrain indices and categorical variables as auxiliary information. Geoderma 171-172, 35-43.

\section{How to cite this article:}

Juvaria Jeelani, Nayar Afaq Kirmani, Javed Ahmad Sofi, Shakeel Ahmad Mir, Javed Ahmad Wani, Rehana Rasool and Syed Sadat. 2017. An Overview of Spatial Variability of Soil Microbiological Properties using Geostatistics. Int.J.Curr.Microbiol.App.Sci. 6(4): 1132-1145. doi: https://doi.org/10.20546/ijcmas.2017.604.139 